\title{
Literasi Etika Pergaulan Dan Pendidikan Seks
}

\author{
Nawari Ismail1, Muh Samsudin² \\ ${ }^{1}$ Program Studi Komunikasi dan Penyiaran Islam, Fakultas Agama Islam, Universitas Muhammadiyah Yogyakarta; \\ Email: nwrismaiel@umy.ac.id \\ DOI: $10.18196 / p p m .34 .289$
}

\section{ABSTRAK}

Kegiatan ini berupaya untuk meningkatkan pemahaman dan perilaku pergaulan dan pendidikan seks masyarakat. Secara khusus kegiatan ini bertujuan: (1) peningkatan literasi etika pergaulan di kalangan perempuan, khususnya ibu-ibu yang telah memilikianak-anak dan remaja. (2) peningkatan literasi pendidikan seks di kalangan ibu-ibu dan remaja. Metode kegiatan dilakukan denga workshop, penyuluhan, dan sosialisasi melalui banner. Workshop melibatkan pimpinan lembaga di dusun yaitu kepala dusun, ketua RT dan kader PKK. Penyuluhan ditujukan kepada masyarakat umum dengan menjadikan wakil kader PKK, dan remaja Karang Taruna sebagai fasilitator dan narasumbernya. Sosialisasi berupa banner ditempatkan di lokasi strategis yaitu: rumah ketua RT, gereja, pos ronda, dan papan informasi kampung. Kegiatan ini memberika dampak positif bagi masyarakat Juwono, terkhusus bagi ibu-ibu dan dari kalangan remaja. Sebab hampir separuh ibu-ibu dan remaja berubah menjadi lebih baik lagi dalam beretika dan bertambah pengetahuannya tentang pendidikan seks.

Kata Kunci: Literasi, etika pergaulan, pendidikan seks.

\section{PENDAHULUAN}

Modernisasi dan globalisasi telah memberikan dampak positif dan negatif. Di antara dampak positifnya adalah semakin mudahnya masyarakat dalam mengakses berbagai media massa dan media sosial. Sementara di antara dampak negatifnya adalah semakin memudahkan masyarakat, khususnya generasi muda dalam mengakses informasi yang tidak baik seperti pornografi, pornoaksi, dan budaya pergaulan yang tidak sesuai dengan budaya lokal dalam masyarakat. Hal ini nampak dari persoalan pergaulan dan hubungan antar jenis kelamin yang semakin longgar. Ironisnya lagi kecenderungan ini telah merambah bukan hanya di kalangan masyarakat perkotaan, namun juga dalam masyarakat perdesaan. Tidak terkecuali di masyarakat yang ada di Juwono Desa Wates Kecamatan Dukun Kabupaten Magelang.

Dusun Juwono Desa Wates Kecamatan Dukun Kabupaten Magelang terdapat beberapa organisasi kepemudaan seperti kelompok remaja gerejani, masjid, Kelompok Karang Taruna, Kelompok Pustaka Desa yang bertujuan untuk terus mengembangkan pendidikan umum dan keagamaan seperti TPA serta kegiatan kepemudaan. Mayoritas penduduk beragama Katolik. Musyawarah juga merupakan hal yang biasa dilakukan oleh masyarakat Dusun Juwono dalam rangka mencari solusi di berbagai bidang. Kegiatan musyawarah biasanya dilakukan dalam pertemuan RT, arisan antar RT, rapat ibu-ibu PKK, atau Karang Taruna. Sebagian besar masyarakat bertumpu pada sektor pertanian. Mereka menanam cabai, padi, terong, sawi, kankung, sayur-sayuran serta rempah-rempah lainnya. Selain itu juga, mereka menanam pohon yang berbuah tahunan seperti mangga, rambutan, dan salak. Masyarakatnya memiliki berbagai jadwal rutin dalam berbagai kegiatan perkumpulan, seperti PKK, Karang Taruna, maupun perkumpulan khusus bapak-bapak. Perkumpulan rutin ini dilakukan sebagai sarana untuk lebih guyub rukun antar warga, sosialisasi, serta membahas program yang telah direncanakan guna mencapai tujuan bersama.

Hampir setiap rumah tangga memiliki televisi, dan radio. Orang dewasa dan kaum milenial, bahkan sebagian anak-anak sudah memiliki handphone. Televisi merupakan salah satu media utama yang digunakan anggota masyarakat sebagai hiburan dan pengisi waktu 
senggang. Sementara di kalangan remaja sangat akrab dengan media sosial. Sebagaimana di berbagai daerah, walaupun di pedesaan, perubahan sosial budaya dalam masyarakat terus berlangsung. Baik itu karena pengaruh positif atau negatif dari media maupun juga kontak-kontak langsung dengan dunia luar. Interaksi sosial di kalangan remaja dan individu semakin lemah, dan pergaulan antar individu yang didasarkan atas nilai-nilai setempat dan agama semakin tergerus. Hanya saja masih banyak orang tua dan remaja di dusun Juwono masih kurang memahami, dan memperhatikan etika pergaulan mereka ketika sedang berinteraksi dengan lingkungan sekitarnya. Mereka juga kurang pengetahuan tentang pentingnya pendidikan seks sejak dini. Hal ini mempengaruhi pada perilaku mereka yang bertolak belakang dengan norma dan agama (Wawancara dengan Permadi, Ketua Wilayah Dusun Sempon-Juwono, Januari 2020). Kegiatan ibu-ibu PKK Dusun sudah berjalan dengan baik. Ada tempat pertemuan yang mampu menampung banyak ibu-ibu dan remaja sekaligus yaitu di rumah Ketua RW 2. Masyarakat dusun ini juga memiliki kekompakan dalam memahami pentingnya kebersamaan dalam menoreh kemajuan, walaupun ada perbedaan agama.

Secara umum kegiatan ini bertujuan untuk memberdayakan masyarakat dalam menghadapi perubahan nilai-nilai pergaulan yang tidak sesuai dengan nilai-nilai agama dan budaya lokal, sehingga masyarakat memiliki kewaspadaan dalam mencegah dan menanggulangi prilaku pergaulan yang tidak sehat. Secara terinci kegiatan ini bertujuan untuk peningkatan literasi etika pergaulan dan pendidikan seks di kalangan perempuan, khususnya ibu-ibu dan di kalangan remaja. Literasi untuk peningkatan pengetahuan dan kesadaran masyarakat tentang berbagai aspek tetap diperlukan karena dari waktu ke waktu masyarakat selalu dihadapkan kepada banyak tantangan (Damayantie, Augustia Rahma. 2015.) Tidak terkecuali dalam aspek peningkatan etika pergaulan dan pendidikan seks karena masyarakat pada era globalisasi saat ini terus memperoleh terpaan informasi dari berbagai media. Pemberdayaan kepada mereka berupa peningkatan pemahaman dan cara melakukan pergaulan dan pendidikan seks, sehingga anggota masyarakat memiliki kebertahanan dan terhindar dari efek negatif media dan budaya luar yang tidak sesuai dengan budaya lokal. Orang tua perlu diberikan literasi melalui pemberdayaan karena pengetahuan dan sikap mereka tentang pendidikan seks dan pergaulan berpengaruh terhadap pengetahuan dan sikap anak-anakya (Anugraheni, Elfrida. 2012).

\section{METODE PELAKSANAAN}

Sasaran program pendampingan adalah ibu-ibu dan remaja Dusun Juwono. Untuk mencapai tujuan serta target, kegiatan ini dilakukan melalui berbagai cara yaitu: Pertama, Pre-test dan post-tes sebelum dan sesudah pelaksanaan kegiatan. untuk mengetahui ada-tidaknya perubahan kesadaran dan perilaku etika pergaulan dan pendidikan seks. Quesioner diberikan kepada 21 orang responden yang terdiri dari 10 orang ibu-ibu dan 11 orang remaja. Pelaksanaannya dikoordinir mahasiswa KKN.

Kedua, workshop dan musyawarah. Workshop dilakukan di lingkungan kader PKK Dusun dan kader Karang Taruna. Narasumber adalah pengabdi dibantu oleh mahasiswa KKN. Seusai workshop dilakukan musyawarah di antara peserta dan narasumber tentang rencana kegiatan berikutnya.

Ketiga, penyuluhan dilakukan di sekretariat RT 2. Sasarannya adalah ibu-ibu dan remaja di Juwono. Penyuluh adalah 2 orang kader PKK untuk ibu-ibu, dan 2 orang kader Karang Taruna untuk remaja putera-puteri yang sebelumnya telah diberikan materi tentang etika pergaulan dan pendidikan seks melalui workshop. 
Keempat, sosialisasi permanen melalui empat banner yang berisi pengingatan bagi masyarakat tentang etika pergaulan dan pendidikan seks yang bijak dan cerdas. Banner tersebut dipasang di depan rumah Ketua RT 2, pos Kamling, halaman gereja dan papan informasi RT.

\section{HASIL DAN PEMBAHASAN}

\section{A. Hasil Pelaksanaan Kegiatan}

\section{Pre-Tes}

Berikut adalah hasil pretest. Pengetahuan tentang etika pergaulan dari kalangan ibu-ibu dan remaja ada di tabel 1 dan 2 . Pengetahuan tetang pendidikan seks ada di tabel 3 dan 4 .

\section{a. Pengetahuan Etika Pergaulan}

Tabel 1. Tingkat Pengetahuan

Etika Pergaulan Ibu-Ibu

\begin{tabular}{|c|c|c|}
\hline Kategori & $\mathrm{N}$ & $\%$ \\
\hline Tinggi & 9 & $90 \%$ \\
\hline Sedang & 0 & $0 \%$ \\
\hline Rendah & 1 & $10 \%$ \\
\hline
\end{tabular}

Sumber: Data Primer, Januari 2020

Tabel 2. Tingkat Pengetahuan

Etika Pergaulan Remaja

\begin{tabular}{|c|c|c|}
\hline Kategori & N & $\%$ \\
\hline Tinggi & 3 & $27,27 \%$ \\
\hline Sedang & 4 & $36,36 \%$ \\
\hline Rendah & 4 & $36,36 \%$ \\
\hline
\end{tabular}

Sumber: Data Primer, Januari 2020

b. Pengetahuan Pendidikan Seks

Tabel 3. Tingkat Pengetahuan

Pendidikan Seks Ibu-Ibu 


\begin{tabular}{|c|c|c|}
\hline Kategori & $\mathrm{N}$ & $\%$ \\
\hline Tinggi & 2 & $20 \%$ \\
\hline Sedang & 4 & $40 \%$ \\
\hline Rendah & 4 & $40 \%$ \\
\hline
\end{tabular}

Sumber: Data Primer, Januari 2020

Tabel. 4 Tingkat Pengetahuan

Pendidikan Seks Remaja

\begin{tabular}{|c|c|c|}
\hline Kategori & $\mathrm{N}$ & $\%$ \\
\hline Tinggi & 3 & $27,27 \%$ \\
\hline Sedang & 5 & $45,45 \%$ \\
\hline Rendah & 3 & $27,27 \%$ \\
\hline
\end{tabular}

Sumber: Data Primer, Januari 2020

\section{Workshop}

Workshop dilakukan hari Kamis, 16 Januari 2020 pukul 15.30 WIB di kediaman Bapak Ketua RT 02. Pesertanya terdiri dari Ketua RT 02, Bapak Martanto, enam orang ibu-ibu PKK dan enam orang remaja Karang Taruna.

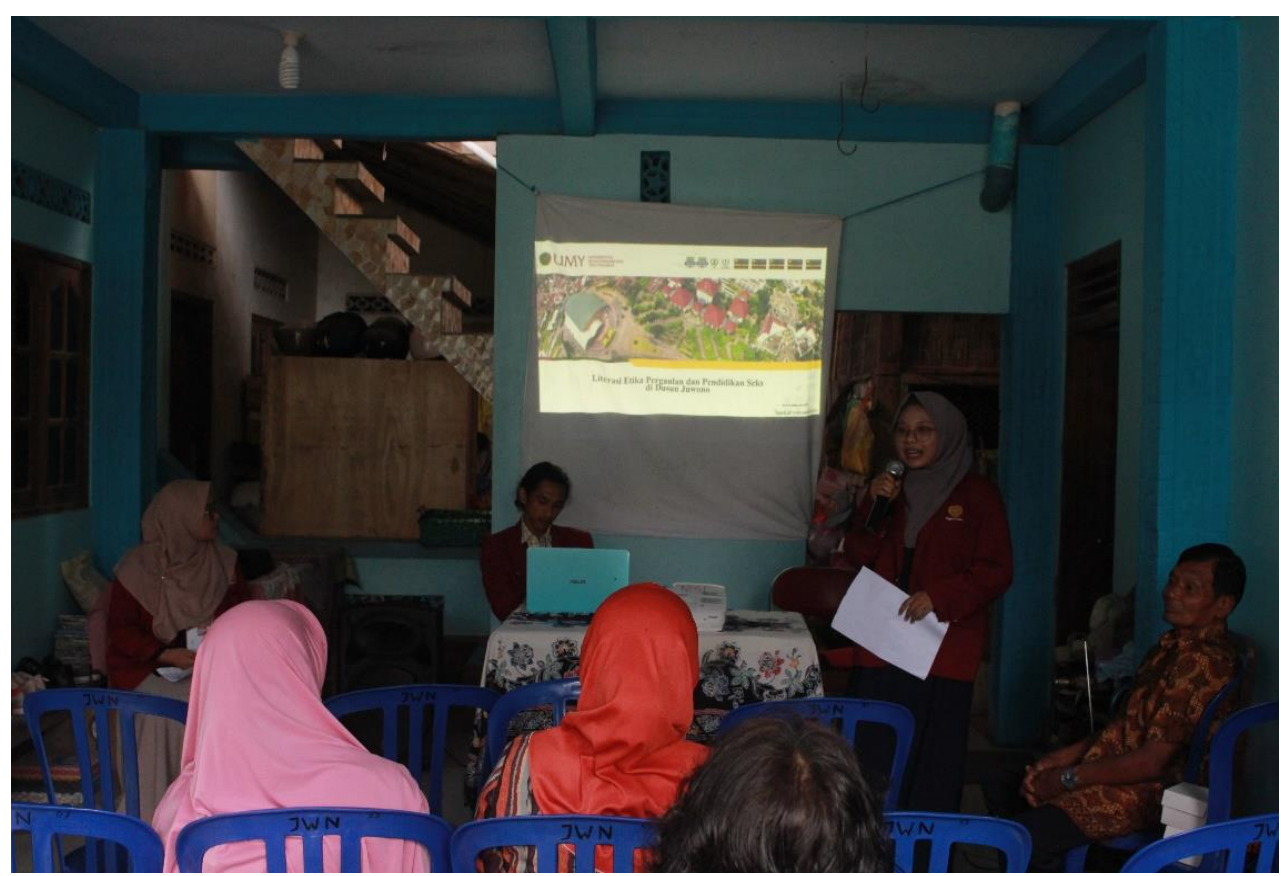

Gambar 1. Pemberian Materi Workshop untuk Kader PKK dan Karang Taruna 


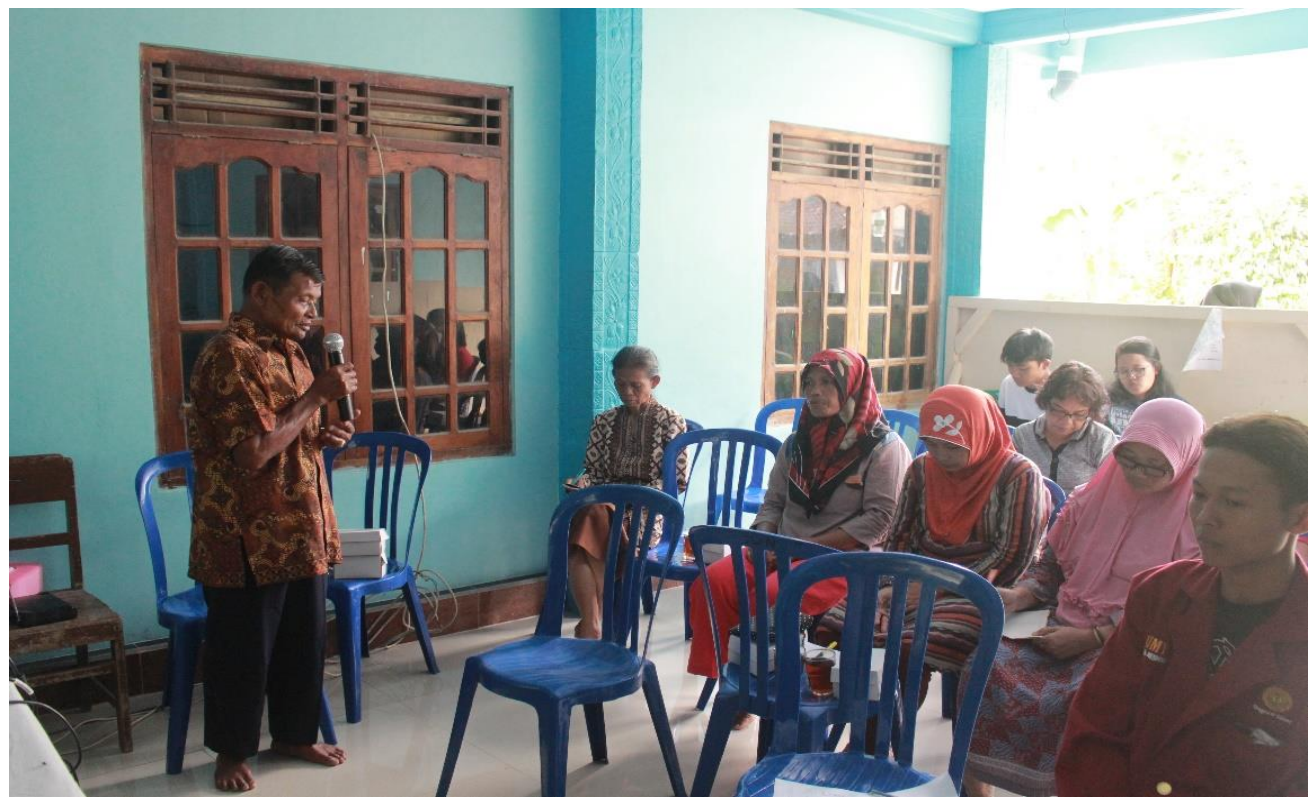

Gambar 2. Sambutan Ketua RT 02 pada Kegiatan Workshop

Dari kader PKK Juwono dihadiri oleh enam orang yakni Ibu M. Tanrah, Ibu Tri Maryati, Ibu Martitik, Ibu Ika Yuniarti, Ibu Musrini, Ibu Sukarti. Dari kader Karang Taruna dihadiri oleh enam orang yaitu Alfansus A, Fabiana R.D.A, Bernadeta D.J, Yulius, Ipung dan Theo.

Pelaksanaan workshop dimulai dengan pembukaan, sambutan dari Ketua RT 02 serta dilanjutkan dengan sambutan dari pengabdi dan narasumber, dilanjutkan dengan musyawarah antara narasumber dengan peserta workshop, acara diakhiri dengan pembacaan kesimpulan dan penutup.

Materi workshop meliputi: (1) Etika pergaulan dengan orang tua, tetangga, teman sebaya dan lawan jenis, (2) Organ dan fungsi organ reproduksi, kesehatan reproduksi, dan penyakit. Penyampaian materi disajikan dalam bentuk power point dengan bantuan LCD. Para peserta dibagikan foto kopi materi.

Hasil workshop meliputi; (1) Pemahaman mengenai literasi etika pergaulan dan pendidikan seks yang diwakili dari kader PKK, Karang Taruna dan ketua RT 02. Mereka semakin paham tentang pentingnya etika pergaulan dan pendidikan seks sejak dini untuk anggota keluarganya. (2) Peserta workshop bersepakat untuk mengadakan penyuluhan kepada masyarakat sesuai denga status mereka yakni ibu-ibu dan remaja. (3) Penyuluhan akan dilaksanakan pada Selasa, 21 Januari 2020 untuk ibu-ibu PKK pukul 13.30 di rumah Ketua RT 02 (Bapak Martanto) dan Jum'at, 24 Januari 2020 untuk remaja pukul 19.00 di rumah Mbak Dwi (Ibu Tri Maryati). (4) Bapak RT 02, kader Karang Taruna dan Ibu-Ibu PKK siap memasang banner.

\section{Penyuluhan kepada Kaum Ibu-Ibu PKK dan Remaja}

Berdasarkan kesepakatan dengan warga, penyuluhan dilaksanakan satu minggu setelah pelaksanaan workshop. Khusus kegiatan penyuluhan ibu-ibu PKK dilakukan pada hari Selasa, 21 Januari 2020 pukul 13.30-selesai. Pematerinya ibu Sukarti dan ibu Ika Yuniarti. Penyuluhan ibu-ibu PKK dihadiri sejumlah 17 orang. Terdiri dari satu Ketua PKK (Ibu Martutik) dan 16 ibu-ibu yang memiliki anak, dan cucu. 


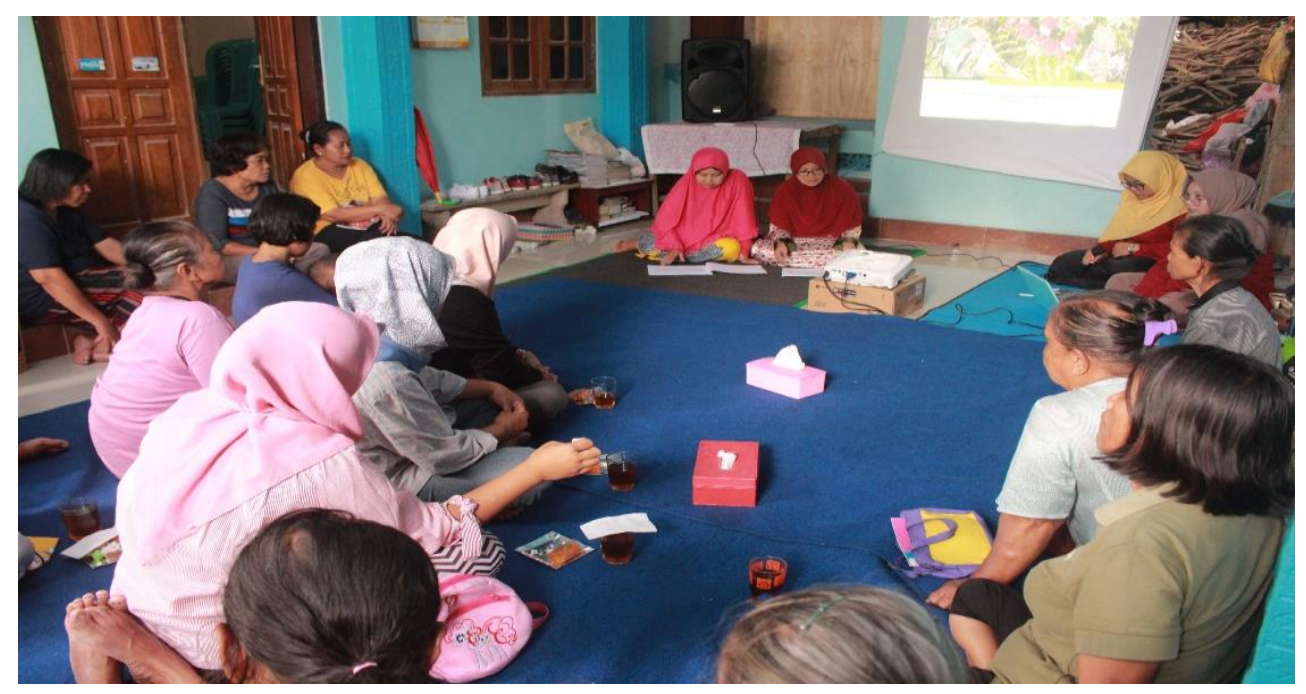

Gambar 3. Penyuluhan Kepada Ibu-ibu Juwono oleh 2 Kader PKK

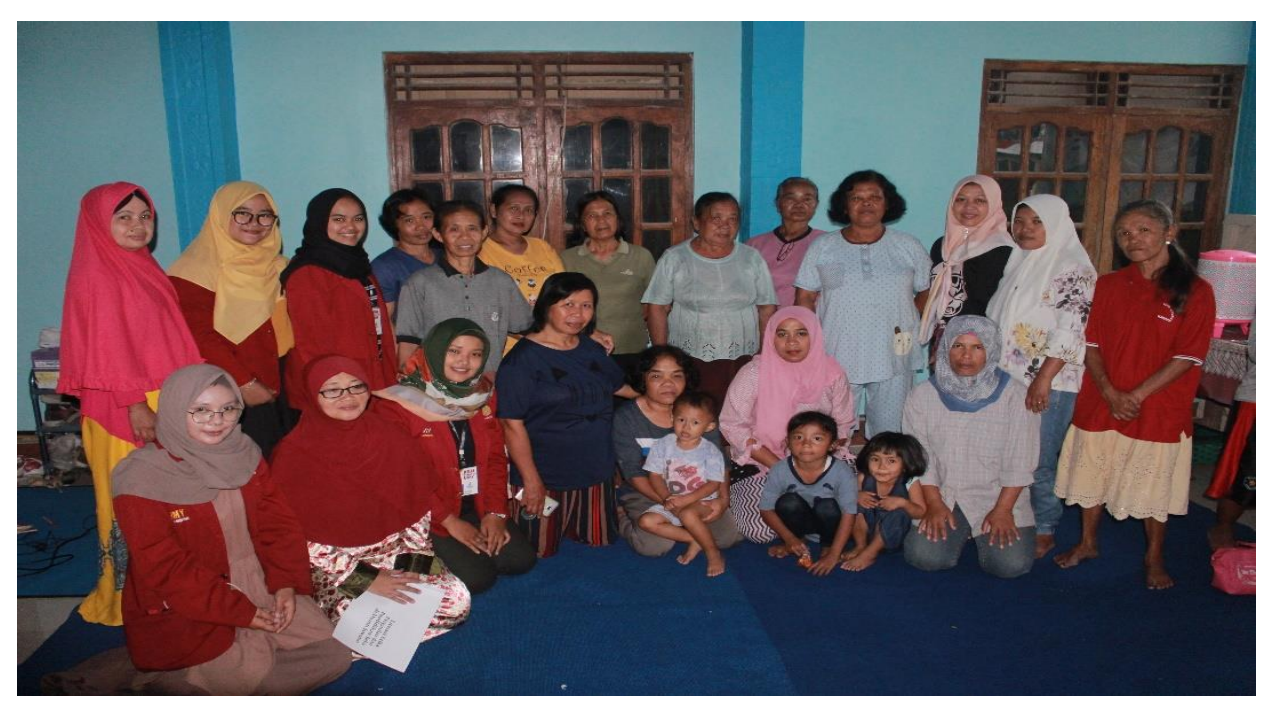

Gambar 4. Foto Bersama Setelah Workshop Penyuluhan

Penyuluhan dimulai dengan pembukaan, sambutan dari Ketua PKK. Kemudian sambutan dari pengabdi dan mahasiswa KKN. Pemberian materi diselingi diskusi antara narasumber dengan peserta. Acara diakhiri dengan penutupan serta foto bersama dengan peserta.

Penyuluhan untuk remaja Karang Taruna dilaksanakan pada hari Jum'at, 24 Januari 2020 pukul 19.00-selesai di rumah saudari Dwi (Ibu Tri Maryati). Pesertanya sebanyak 20 orang, terdiri dari 11 laki-laki dan 9 perempuan. Narasumbernya adalah Dwi dan Rina Penyuluhan diawali dengan pembukaan, sambutan dari Ketua Karang Taruna, pengabdi dan mahasiswa KKN. Setelah itu dilanjutkan dengan pemberian materi dan diskusi. Acara diakhiri dengan penutup. 


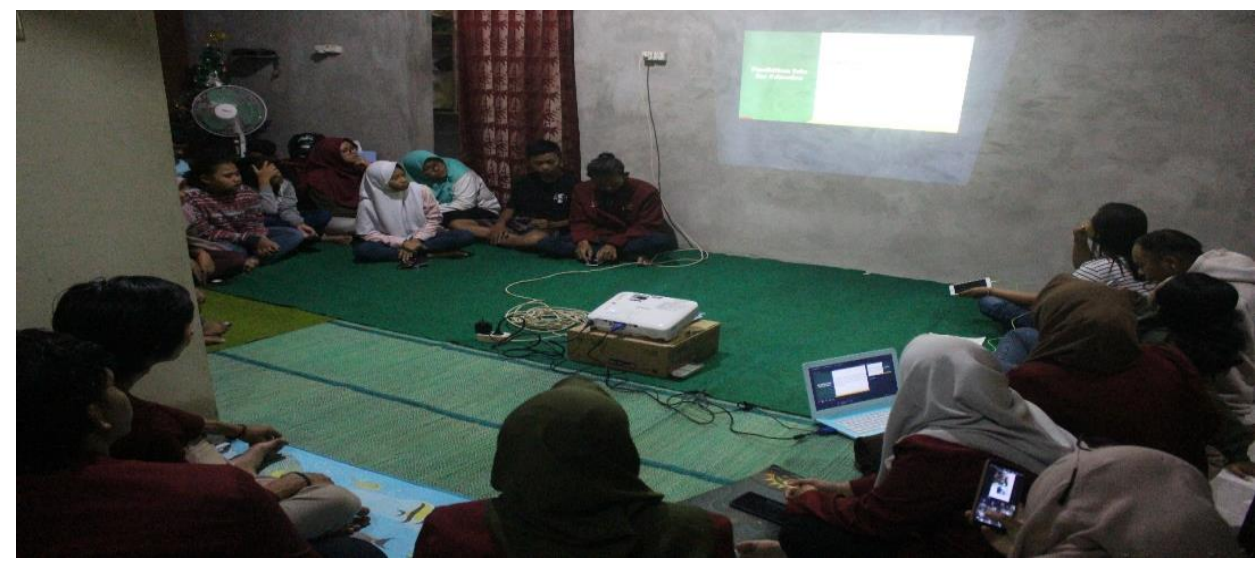

Gambar 5. Penyuluhan Etika Pergaulan dan Pendidikan Seks Oleh Dua Kader Karang Taruna kepada Remaja di Juwono

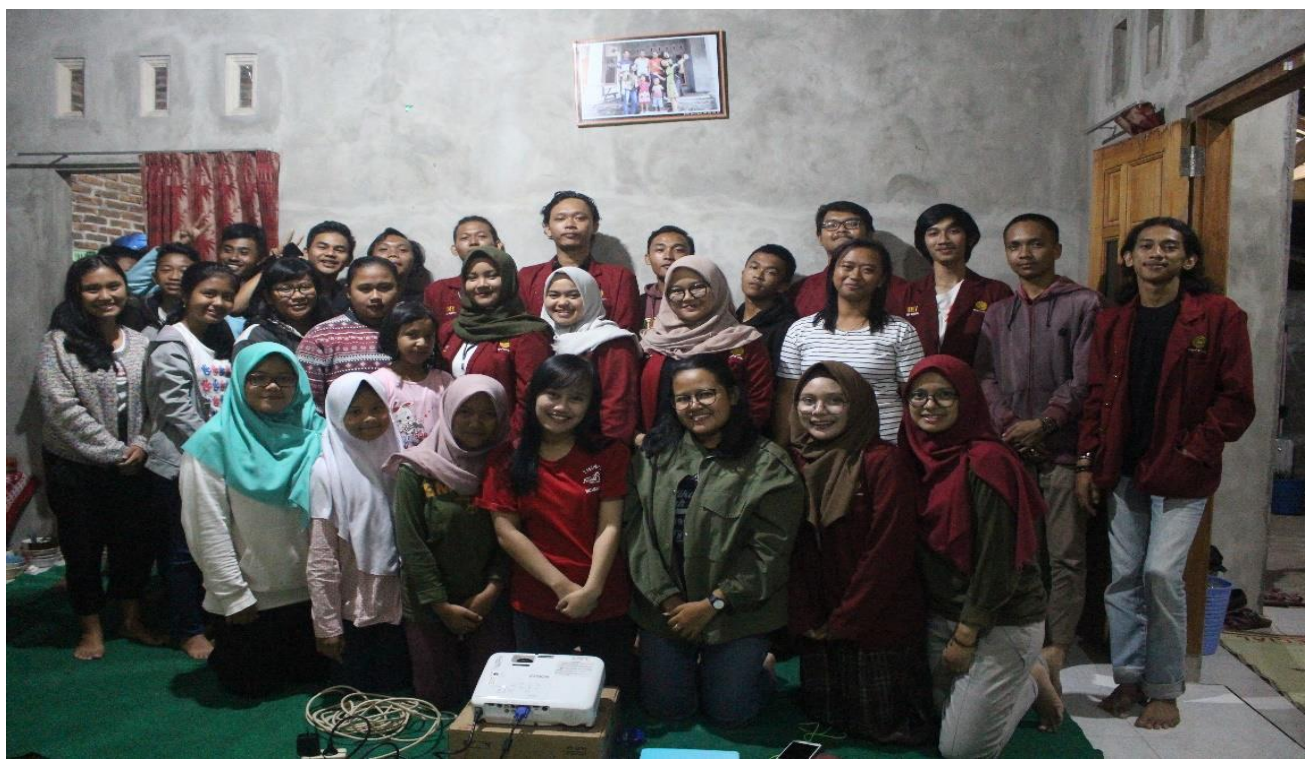

Gambar 6. Foto Bersama Setelah Penyuluhan

Materi penyuluhan kepada ibu-ibu dan remaja meliputi: (1) Etika pergaulan dengan orang tua, tetangga, teman sebaya dan lawan jenis. (2) Pendidikan seks, kesehatan reproduksi, organ, fungsi organ reproduksi, dan penyakit seksual. Materi disajikan melalui LCD, dan foto kopi makalah.

Para peserta dari kalangan ibu-ibu dan remaja memperoleh ilmu baru dan manfaat dari penyuluhan tersebut. Berikut ini komentar dari ibu Ponirah:

Apa yang telah disampaikan oleh ibu Sukarti dan ibu Ika Yuniarti sangat bermanfaat bagi saya pribadi mbk. Karena dengan ilmu yang telah saya dapatkan dari workshop ini, saya bisa mengetahui etika pergaulan yang sebenarnya serta menambah pengetahuan saya akan pentingnya pendidikan seks bagi anggota keluarga. Sehingga dengan ilmu, saya akan memberikan penjelasan dan contoh yang baik kepada anak serta anggota keluarga saya mbak.

\section{Dari remaja, menurut Rina}

Sangat bermanfaat, karena dengan pengetahuan pendidikan seks ini, saya bisa mengetahui, dan memahami peran dari jenis gender serta menyadari masalah akan 
timbul akibat dari seks bebas itu sendiri apabila kita tidak memperhatikan dan berhati-hati dalam bergaul.

Adapun pendapat dari bapak Martanto (Ketua RT 02) yakni:

Literasi yang diberikan dari bapak Nawari dan Mahasiswa KKN UMY Kelompok 026 sangat bermanfaat bagi warga Juwono, karena warga mendapatkan ilmu baru dan memahami akan pentingnya etika dalam bergaul serta pentingnya pemberian pendidikan seks sejak dini bagi anak. Dengan adanya pemberian literasi ini diharapkan orang tua dan remaja lebih baik lagi dalam berperilaku dan bergaul di lingkungan sekitarnya. Sehingga mereka akan terhindar dari perilaku abnormal di masyarakatnya.

\section{Sosialisasi Melalui Banner}

Pemasangan banner memiliki nilai strategis karena selain bisa bertahan lama juga setiap warga Juwono bisa membaca dan menjadi pengingat setiap saat. Empat banner ini diletakkan di Rumah bapak RT 02, halaman gereja, pos Kamling, dan papan informasi RT.

Konten baner meliputi tahapan pendidikan seksualitas anak, hal-hal yang perlu diingat dalam pendidikan seks untuk anak, dan tata cara pergaulan yang baik.
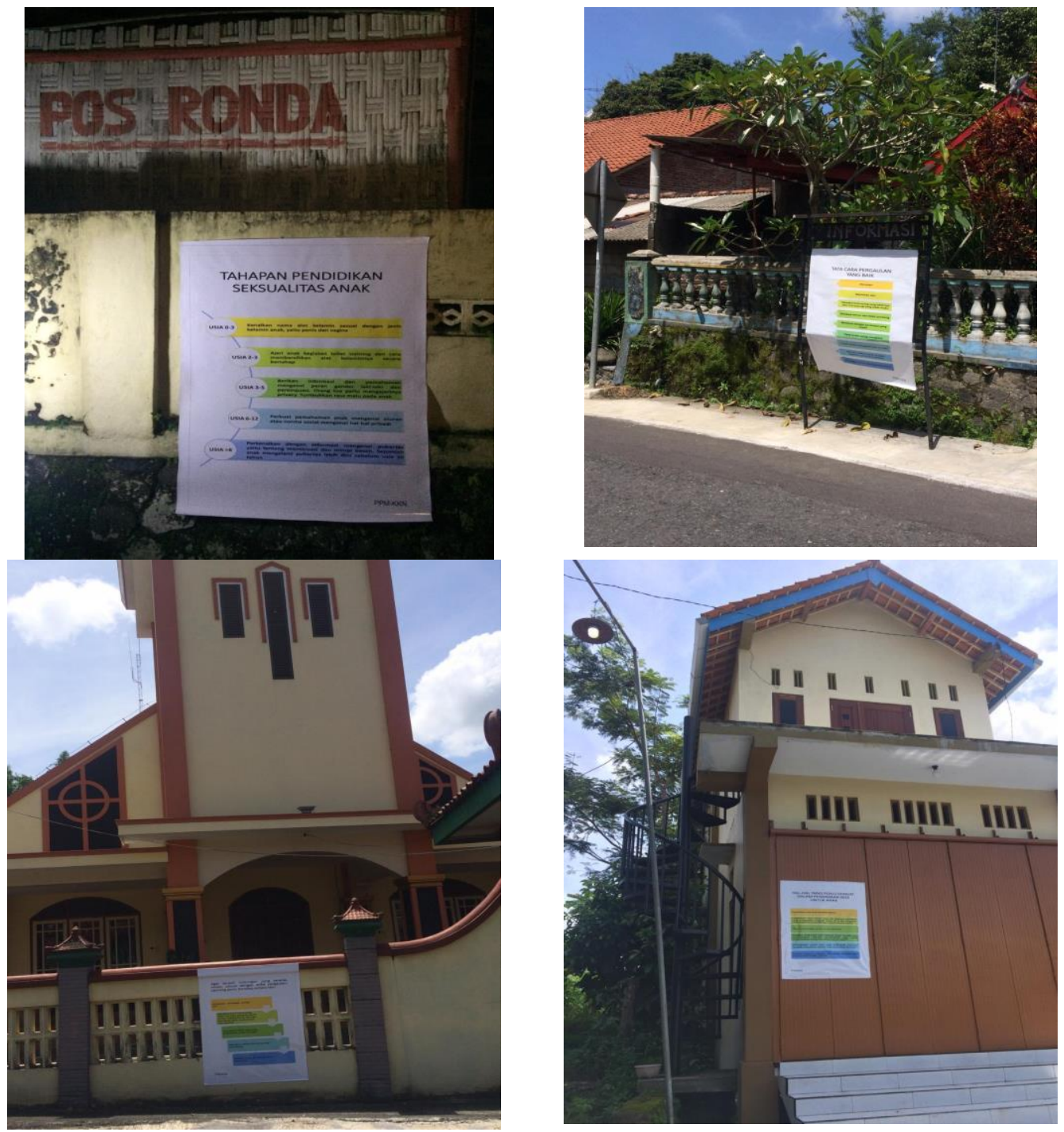


\section{Dampak}

Gambar 6. Foto Banner Sosialisasi Etika Pergaulan dan Pendidikan Seks

a. Pengetahuan Etika Pergaulan

Table 5. Tingkat Pengetahuan Etika Pergaulan Ibu-Ibu PKK

\begin{tabular}{|c|c|c|}
\hline Kategori & $\mathbf{N}$ & $\mathbf{\%}$ \\
\hline Tinggi & 7 & $43,75 \%$ \\
\hline Sedang & 8 & $50 \%$ \\
\hline Rendah & 1 & $6,25 \%$ \\
\hline
\end{tabular}

Sumber: Data Primer Januari 2020

Tabel 6. Tingkat Pengetahuan Etika Pergaulan Remaja Karang Taruna

\begin{tabular}{|c|c|c|}
\hline Kategori & $\mathbf{N}$ & $\mathbf{\%}$ \\
\hline Tinggi & 8 & $44,44 \%$ \\
\hline Sedang & 4 & $22,22 \%$ \\
\hline Rendah & 6 & $33,33 \%$ \\
\hline
\end{tabular}

Sumber: Data Primer Januari 2020

b. Pengetahuan Pendidikan Seks

Table 7. Tingkat Pengetahuan Pendidikan Seks Ibu-Ibu PKK

\begin{tabular}{|c|c|c|}
\hline Kategori & $\mathbf{N}$ & $\mathbf{\%}$ \\
\hline Tinggi & 7 & $43,75 \%$ \\
\hline Sedang & 5 & $31,25 \%$ \\
\hline Rendah & 4 & $25 \%$ \\
\hline
\end{tabular}

Sumber: Data Primer Januari 2020

Tabel 8. Tingkat Pengetahuan Pendidikan Seks Remaja Karang Taruna

\begin{tabular}{|c|c|c|}
\hline Kategori & $\mathbf{N}$ & $\mathbf{\%}$ \\
\hline Tinggi & 10 & $55,56 \%$ \\
\hline Sedang & 4 & $22,22 \%$ \\
\hline Rendah & 4 & $22,22 \%$ \\
\hline
\end{tabular}

Sumber: Data Primer Januari 2020

\section{B. Pembahasan Hasil Pelaksanaan Kegiatan}

\section{Teknologi Informasi dan Komunikasi di Masyarakat Rural}

Proses internasionalisasi budaya Barat ke seluruh pelosok di dunia terus menggelinding. Internasionalisasi tersebut didukung oleh kemajuan teknologi informasi dan komunikasi (Robertson dalam Beckford dan Thomas, 1991). Dalam kasus di Indonesia, 
perkembangan tekonoligi dan media komunikasi tersebut bukan hanya tersebar di daerah perkotaan, namun juga di perdesaan, termasuk di lokasi pengabdian ini dilakukan.

Di Dusun Pakis hampir kepemilikan handphone telah menjadi fenomena yang biasa, dan hampir setiap keluarga telah memiliki televisi. Handphone telah menjadi kebutuhan orang dewasa, kaum generasi muda, bahkan banyak anak-anak pun telah memilikinya. Generasi musa telah menjadikan kepemilikan handphone sebagai bagian dari gaya hidup (life style), baik dari kalangan laki-laki maupun perempuan. Jika abad ke-20 globalisasi ditandai dengan gaya hidup dalam 3F (Fashion, Food, and Fun/Pakaian, Makanan, dan Hiburan), maka gaya hidup generasi muda saat ini ditandai dengan kepemilikan gawai (gadget) berupa handphone yang canggih. Semakin canggih gawai yang dimiliki semakin memberikan 'prestise' bagi yang memilikinya dan kian bebas berselancar dalam melakukan media sosial.

Masalahnya adalah dari berbagai kajian media sosial telah banyak memberikan dampak negatif, selain tentu ada dampak positifnya. Di antara dampak negatif tersebut adalah menyasar pada aspek psikologis seperti mudah marah, meniru perilaku buruk dari gadget, dan menurunya daya konsentrasi ( Syifa, Setianingsih, Sulianto, 2019; Syahyudin, 2019), dan perilaku moral seperti suka membangkang kepada orang tua, turunnya amalan ibadah, serta pornografi (Alshare, Abdelbaset and Eneizan, 2019; Khairuni, 2016). Hal ini terbukti dari riset pendahuluan yang dilakukan pengabdi, dari informasi awal diketahui ada beberapa remaja di lokasi pengabdian yang berperilaku seperti tersebut.

\section{Dampak Kegiatan}

Kegiatan pengabdian yang dilakukan pengabdi telah memiliki dampak yang cukup berarti bagi warga ibu-ibu dan remaja di Juwono. Dari kalangan ibu-ibu tingkat pengetahuan etika pergaulan pada saat pretest sekitar $90 \%$ yang tinggi, $0 \%$ masuk kategori sedang dan $10 \%$ rendah. Saat posttest kepada ibu-ibu menunjukkan mereka mengalami perubahan yakni $43,75 \%$ tinggi, 50\% sedang dan 6,25\% rendah. Sementara untuk tingkat pengetahuan pendidikan seks ibu-ibu saat pre-test 20\% tinggi, 40\% sedang dan $40 \%$ rendah. Namun saat dilakukan post-test mengalami perubahan yang cukup signifikan dengan skor presentase sebesar $44 \%$ tinggi, $31 \%$ sedang dan $25 \%$ rendah.

Pengetahuan tentang etika pergaulan remaja: pada saat pretest kategori tinggi sebesar $27 \%$, sedang $36 \%$ dan redah $36 \%$. Setelah post-test berubah signifikan yakni tinggi $=44 \%$, sedang $=22 \%$, dan rendah $=33 \%$. Untuk tingkat pengetahuan pendidikan seks pada saat pre-test sebesar $27 \%$ tinggi, $46 \%$ sedang dan $27 \%$ rendah. Setelah posttest berubah menjadi $56 \%$ tinggi, $22 \%$ sedang dan $22 \%$ rendah.

\section{Prinsip Pemberdayaan}

Pada hakikatnya pemberdayaan memiliki makna upaya dari, oleh dan untuk masyarakat, walaupun dari pihak luar tetap melakukan berbagai stimulasi di awal. Prinsip ini juga dipakai dalam kegiatan literasi etika pergaulan dan pendidikan seks ini. Prinsip ini terlihat dalam berbagai tahap: Pertama, saat perencanaan program, pengabdi melibatkan berbagai stakeholder lokal terkait. rencana pelaksanaan, waktu, tempat, narasumber, serta rencana teknis kegiatan seperti LCD, sound sistem, konsumsi, dan undangan.

Kedua, ketika kegiatan workshop, pengabdi selain memberi materi juga melakukan msyawarah mengenai materi dan tentang kegiatan lanjutannya. Ketiga, narasumber dalam penyuluhan sepenuhnya berasal dari kader PKK dan Karang Taruna. Pengabdi dan mahasiswa KKN berperan sebagai pendamping. Keempat, sosialisasi melalui pemasangan banner dilakukan sendiri masyarakat. 


\section{Pemacu dan Kendala}

Kegiatan ini berjalan dengan baik karena ada faktor pemacunya yaitu: (1) Adanya kehendak baik dari kepala dusun sehingga, (2) Pemangku kepentingan terkait dengan kegiatan ini dapat dikordinasi dengan mudah dan baik. Mereka adalah Kepala Dusun, ketua RT, Karang Taruna dan pengurus PKK Dusun Juwono. Kendala hanya berupa ketepatan waktu dalam setiap pelaksanaan karena harus menunggu lengkapnya peserta saat workshop dan penyuluhan. Pelaksanaan kegiatan biasanya baru data dilaksanakan satu jam atau lebih dari waktu yang ditentukan dalam undangan. Hal ini nampaknya terkait dengan budaya penggunan waktu masyarakat.

\section{KESIMPULAN}

Berbagai kegiatan pengabdian ini telah memberikan dampak positif. Dampak terhadap remaja terlihat pada aspek pengetahuan tentang etika pergaulan. Sebelum kegiatan, pengetahuan tinggi hanya $27 \%$, setelah kegiatan menjadi $44 \%$. Pengetahuan remaja tentang pendidikan seksual berubah signifikan. Dampak terhadap ibu-ibu terjadi pada aspek pengetahuan tentang pendidikan seks. Sebelum kegiatan , pengetahuan tinggi hanya $20 \%$, setelah kegiatan menjadi $44 \%$.

Sebagai tindak lanjut dari pengabdian ini, penting pihak-pihak terkait dengan pengembangan moralitas masyarakat untuk peningkatan pemelekan pengetahuan masyarakat tentang etika pergaulan dan pendidikan seks di kalangan remaja dan orang tua.

\section{UCAPAN TERIMA KASIH}

Terima kasih saya sampaikan kepada pihak Lembaga Penelitian, Publikasi, dan Pengabdian kepada Masyarakat (LP3M) Univetsitas Muhammadiyah Yogyakarta yang telah memberikan hibah, sehingga pengabdian ini dapat dilaksanakan. Juga kepada mahasiswa KKN yang membantu kegiatan ini. Ucapan terima kasih yang tidak terhingga juga diucapkan kepada informan, partisipan aktif dari pimpinan lembaga di tingkat Dusun Juwono, serta remaja Karang Taruna dan ibu-ibu anggota PKK yang ada di dusun tersebut.

\section{DAFTAR PUSTAKA}

Ahmad, M.Yusuf. 2015. Etika Pergaulan Islami Santri MA di Pesantren Jabal Nur Kecamatan Kandis Kabupaten Siak. Riau: UIR.

Alshare, Fathi; Alkhawaldeh, Abdelbaset dan Eneizan, Bilal M. 2019, Social Media Website's Impact on Moral and Social Behaviour of the Students of University. International Journal of Academic Research in Business and Social Science. Vo. 0 No. 3. 2019: 169-182.

Anugraheni, Elfrida. 2012. Hubungan Pegetahuan dan Sikap Orang Tua tentang Pendidikan Seks dengan Tindakan Orang Tua dalam Pemberian Pendidikan Seks pada Remaja. Jember: UNEJ.

Damayantie, Augustia Rahma. 2015. Literasi Dari Era Ke Era. Yogyakarta: UNY.

Khairuni, Nisa. Dampak Positif dan Negatif Sosial Media terhadap Pendidikan Akhlak Anak, Jurnal Edukasi. Vo. 2. No. 1, 2016: 91-106. Robertson dalam Beckford dan Thomas, 1991. The Changing Face of Religion. London: Sage.Syahyudin, Dindin. Pengaruh Gadget terhadap Pola Interaksi Sosial dan Komunikasi Siswa, Jurnal Guna HUmas, vol. 2, No. 1, 2019: 271-282). Syifa, Layyinatus; Setianingsih, Eka Sari; Sulianto, Joko. 2019. Dampak Penggunaan Gadget terhadap Psikologi Pada Anak Sekolah Dasar. Jurnal Pendidikan Guru Sekolah Dasar, vol. 3 No. 4, 2019, 527-533 